\title{
The Behaviour of Asset Return and Volatility Spillovers in Turkey: A Tale of Two Crises*
}

\author{
Oscar Bajo-Rubio \\ Professor, Castilla La Mancha University, Department of Economics \\ oscar.bajo@uclm.es \\ Burcu Berke \\ Assistant Professor, Omer Halisdemir University, Nigde, Department of Economics \\ burcuberke@nigde.edu.tr \\ David McMillan \\ Professor, University of Stirling, Department of Accounting and Finance \\ david.mcmillan@stir.ac.uk
}

September 2016

Revised March 2017

\begin{abstract}
This paper examines return and volatility spillovers between the Turkish stock market with international stock, exchange rate and commodity markets. Our aim is not only to examine spillover behaviour with a large emerging market but also to examine crossasset spillovers and how they vary across two periods of financial market crisis; the dotcom crash and the liquidity-induced financial crisis. This is to be compared with existing work that typically focuses on industrialised countries or single asset markets only. Using the spillover index methodology we uncover an interesting distinction between these two periods of markets stress. Over the dotcom period spillovers are largely between the same asset class, notably two exchange rate series and two international stock markets series. However, in the period including the financial crisis, spillovers both increase and cross asset types and suggest a much greater degree of market interdependence. Understanding this changing nature in spillovers is key for investors, regulators and academics involved in theoretical model development.
\end{abstract}

Keywords: Spillovers, Exchange Rates, Stock Returns, Volatility, Commodity Markets, Turkey

Jel Codes: F31, G12

\footnotetext{
* This paper is based on Burcu Berke's Tubitak 2219 Project. Therefore, this author thanks Tubitak for its support.
} 


\section{Introduction.}

This paper seeks to examine the nature of both return and volatility spillovers for the Turkish stock market emanating from a range of markets and asset types. Turkey is one of the largest emerging economies and sits as a key market straddling Europe and Asia. ${ }^{1}$ However, in comparison to the BRICS and MENA markets, research examining the interaction between the Turkish economy and global markets is relatively less. Therefore, we seek to rectify that by considering spillovers between the Turkish stock market and the stock markets of Germany and the US, together with the Euro and US Dollar exchange rates and a commodity market index. Of note, in motivating this choice, Germany is Turkey's largest trading partner and the US is the world's dominant economy. The inclusion of a commodity index arises because is Turkey is both a producer and importer of oil and natural gas, while it is also a major supplier of minerals. Thus, it is possible that the Turkish stock market will be buffeted by movements in both global stock markets as well as other asset types.

Therefore, we utilise the Diebold and Yilamz (2012) approach to examine the existence and nature of return and volatility spillovers across these markets. The main motivation and contribution of this paper falls into three areas. First, most the spillovers literature focusses on developed markets (as discussed in Section 2 below). Thus, with the growth in importance of emerging markets within portfolio and risk management, it is important to fully understand the links between emerging and developed markets. Related, much of the literature concerns spillovers between markets trading the same asset. However, it is important to recognise that spillovers will cross asset classes and this can have an important impact on portfolio construction and decision-making. Second, recognising the importance of cross-asset analysis, over the recent past,

\footnotetext{
${ }^{1}$ According to the World Bank, as of 2016, Turkey is the $17^{\text {th }}$ largest global economy.
} 
commodity markets have become more integrated with stock markets through the increased usage within portfolio management (e.g., Creti et al, 2013). This is referred to as the financialisation of stocks and may have led to the dynamics of stock and commodity prices changing (Vivian and Wohar, 2012; Black et al, 2014). Third, overarching all these effects is that the past fifteen years have seen two major events particularly, but not exclusively, within equity markets. At the beginning of the 2000 s, international stock markets suffered a decline emanating from the dotcom bubble. A subsequent recovery, from this fall, that began around 2003 was then halted by the onset of the financial crisis that has dominated the financial landscape since.

Therefore, this paper seeks answers to these issues regarding spillover effects between an emerging and developed markets, across asset types and how crises within markets affect the nature of such spillovers. The analysis of spillovers perhaps began with the work of Engle et al (1990) who pioneered the concept of volatility spillovers together with the phenomena of heat wave and meteor shower effects. Here, the former refers to volatility within a market (intra-market volatility) and the latter refers to spillovers between markets (inter-market volatility). Since this work, several authors have proceeded to examine a range of markets and assets for volatility spillover effects (as discussed in Section 2). The analysis of spillover effects has benefitted from the development of the spillover index methodology (Diebold and Yilmaz, 2009, 2012). This approach has allowed the modelling of time-varying spillovers for a larger number of series to be undertaken comparatively easily by using the variance decompositions obtained from a vector autoregression as opposed to estimating multivariate GARCH models, which contain a large number of parameters. This has also seen an extension to modelling both return and variance spillovers. An example of this includes McMillan and Speight (2010), who consider the interaction between returns and volatility in 
exchange rates. Analysing both the first and second moments allows for a fuller understanding of the link between markets and, in our case, across asset types.

In brief preview of our results, we find the nature of spillovers to differ across the dotcom and financial crises, with a notably greater level of interaction between markets in the latter period. Specifically, in the dotcom crisis period, spillovers primarily occur between markets for the same asset type and for the industrialised markets only. The commodity market and the Turkish stock market appear relatively less affected. However, in the financial crisis, not only is the level of spillovers increased, but they occur across all market types.

\section{Literature Review.}

The spillovers literature has largely focussed upon volatility spillovers, although some exceptions (as discussed below) do also consider return spillovers. A key argument for examining volatility spillovers is that the volatility process reveals the degree of assimilation and evaluation of new information by the market. As shown by Ross (1989), price volatility is directly related to the amount of information transmitted to the market. In other words, volatility interaction refers to information transfer between different markets or different assets. Thus, a lack of volatility spillovers between two markets is evidence of rapid and efficient transmission of the information (Inagaki, 2007). Indeed, the presence of volatility spillovers is strongly related to the speed of market adjustment to the new information (Kyle, 1985). Engle et al. (1990) suggest that volatility spillovers result from information processing or policy coordination.

The empirical literature on volatility spillovers largely began through examining spillovers across markets trading the same asset class. Indeed, much of the literature began with an analysis of exchange rate volatility following the events surrounding 
developments in the European Monetary System in the early 1990s (see, for example, Artis and Taylor, 1988; Rose and Svensson, 1994; Sosvilla-Rivero et al., 1999). The possible transmission of volatility between markets was first addressed by Engle et al. (1990) who use daily observations on US dollar exchange rates and find evidence of volatility spillovers across different market locations. In turn, Baillie and Bollerslev (1991) find little evidence in favour of volatility spillovers between the US dollar exchange rate against the British pound, German mark, Swiss franc and Japanese yen.

Further research in this vein includes Laopodis (1998) who reports significant volatility spillovers among a range of Deutschemark exchange rates prior to Germany's reunification, while also noting asymmetric spillover effects, whereby a bad news spillover has a greater impact than a comparable good news one. Hong (2001) finds evidence of simultaneous interactions between the German mark and Japanese yen. Huang and Yang (2002) report that volatility in London and New York causes volatility in Tokyo, with volatility in New York only slightly causing volatility in London. Bubák et al. (2011) report the presence of significant volatility spillovers among the Central European (Czech, Hungarian and Polish) foreign exchange markets. Further to these, Malik (2005) finds that the euro was considerably more volatile compared to the British pound, while Nikkinen et al. (2006) point out that the volatility of the euro significantly affected the expected volatility of the British pound and the Swiss franc. Equally, Inagaki (2007), Antonakakis (2008) and Kitamura (2010) find the presence of volatility spillovers running from the euro to the British pound. In a study of three euro exchange rates, US dollar, Japanese yen and British pound, McMillan and Speight (2010) report that the US dollar rate dominates the other two rates in terms of volatility spillovers.

Following the analysis of exchange rate spillovers, researchers examined stock markets for the presence of similar effects. Bonfiglioli and Favero (2005) detect no 
long-term interdependence between German and US stock markets; however, short-term fluctuations of US share prices spillover to German ones. Caporale et al. (2006) find evidence of volatility spillovers in all cases for US, European, Japanese and South East Asian daily stock market returns. While, Chinzara and Aziakpono (2009) show the presence of both return and volatility transmission between South African and major world equity markets. In turn, Beirne et al. (2013) identify volatility spillovers from mature to emerging stock markets.

A natural extension therefore, is to examine the degree of interdependence between stock returns and exchange rates, with early studies including those of Smith (1992) and Ajayi and Mougoué (1996). Kanas (2000) analyses interdependencies between exchange rate and stock return volatilities for six industrialised countries. Evidence of such spillovers arising from stock return to exchange rate return variations is reported five of these countries (the US, the UK, Japan, France and Canada, the only exception being Germany). This finding is consistent with the growing integration of international financial markets. Similarly, Kanas (2002) finds that stock return volatility is a significant determinant of exchange rate volatility in the US, UK and Japan.

In contrast, Apergis and Rezitis (2001) report spillovers from the foreign exchange market to the stock market, but not in the reverse direction. While, Wu (2005), across seven developed and emerging Asian countries, finds the presence of a two-way feedback relation between stock return and exchange rate volatility. Yau and Nieh (2006) note that Taiwanese and Japanese stock prices interact with each other, there is no comparable relation between exchange rates and the stock prices. Fu et al. (2011) report significant volatility transmission between the Japanese stock and foreign exchange markets.

Since the beginning of the 2000s a growing literature has developed examining 
the links between the commodity and equity markets. The financialisation of commodities, in which they are treated as diversifiable assets in a portfolio, can explain the increased relation between these markets. Although, an increase in correlations could equally be due, in part, to global economic conditions, e.g., the financial crisis (Olson et al., 2014). As such, analysing the connections between the commodity and stock markets, and understanding the extent of information transfers between them has become crucial for both investors and policymakers (Creti et al., 2013).

In respect of commodity markets, much of the literature examines the oil market. The relation between oil price shocks and financial markets was first investigated by Jones and Kaul (1996), Huang et al. (1996) and Sadorsky (1999). The results from this research demonstrate that oil price shocks affect stock returns across a range of markets, including the US, Canada, the UK and Japan. Further evidence is provided by Park and Ratti (2008), who report a significant effect of oil price shocks on real stock returns for the US and 13 European countries. In contrast, Büyükşahin et al. (2010) do not identify any clear evidence for co-movement between several commodity returns and US equity indices prior to the global financial crisis. Although, Miller and Ratti (2009) do report a long-run relation between oil prices and stock markets for six OECD markets. However, this relation appears to vanish after 1999. Further supportive evidence for a relation between commodity and stock markets is reported by Choi and Hammoudeh (2010), Silvennoinen and Thorp (2013), Aloui et al. (2012), Arouri et al. (2012), Mensi et al. (2013), Olson et al. (2014) and Kang et al. (2015) across a range of developed and emerging markets and using a variety of econometric tools.

More recent research considers the relation between commodity and stock markets following the financial crisis. Creti et al. (2013) investigate the links between returns for 25 commodities and stocks, using the S\&P 500 index. They report that 
correlations are highly volatile and particularly so after the start of the crisis. Delatte and Lopez (2013) analyse the relation between the returns of two commodity indices (the Goldman Sachs Commodity Index and the Dow-Jones UBS Commodity Index) and four equity indices (SP500, FTSE100, CAC40, DAX30), and find that the dependence between them is time-varying, symmetrical and intensified during the global financial crisis. This result, indicating an increase in the co-movements between returns on equity and commodities after the start of the crisis in 2008, is also documented by Büyükşahin and Robe (2014) using 17 US commodity and equity futures markets.

\section{Spillovers Methodology.}

The analysis of the spillovers between the different asset classes is based on the spillover index methodology introduced by Diebold and Yilmaz $(2009,2012){ }^{2}$ Prior to the introduction of this model, volatility spillover analysis utilised the GARCH modelling approach. Initially this involved using a two-step process whereby univariate GARCH models are estimated and then any relation between the fitted volatility series is considered. One drawback with this two-step procedure is the loss of efficiency in using a fitted series in subsequent analysis (i.e., errors in variables problem). This concern has led to the use of multivariate-GARCH modelling. However, potentially significant problems beset this approach. Multivariate-GARCH models can involve the estimation of a large number of parameters. This could result in a lack of global convergence or efficiency in estimation because of inevitably tension between parsimony and flexibility. Moreover, there are several multivariate-GARCH specifications allowing, for example, asymmetry and long memory, which raises the issue of the preferred model.

\footnotetext{
2 The discussion and notation below closely follows Diebold and Yilmaz (2012) for the sake of consistency and understanding.
} 
Therefore, we adopt the Diebold-Yilmaz spillover index approach. This in turn is based on a vector autoregressive model (VAR: Sims, 1980) and uses the variance decomposition approach. This allows us to assess the contributions of the shocks to and from each variable in terms of each variable's forecast error variance. Furthermore, by using fixed window rolling estimation, time-varying dynamics of the spillovers can be examined. The usefulness of this measure is that is allows the large range of information provided by variance decompositions to be aggregated into a single value, and hence to concisely convey the degree of spillovers within the markets considered. In short, the spillover index measures the extent of cross-market spillovers as captured by the aggregate share of cross-market error variance in the variance decomposition relative to the total error variance of the markets considered.

Diebold and Yilmaz (2009) use the Cholesky decomposition for the VAR, while Diebold and Yilmaz (2012) implement the generalised VAR framework of Koop et al (1996) and Pesaran and Shin (1998). This latter approach allows the variance decompositions to be invariant to the ordering of the variables within the VAR. We begin with a general $k$-variable and $p$-lagged VAR model:

$$
x_{t}=\sum_{i=l^{p}} \varphi_{i} x_{t-i}+\varepsilon_{t}
$$

Where $x_{t}$ represents the vector of $k$ endogeneous variables, while $\varphi$ is a $k x k$ matrix of parameters for each time lag, $p$, and $\varepsilon_{t} \sim(0, \Sigma)$ is a vector of disturbances that are assumed to be independently and identically distributed over time.

Assuming covariance stationarity, then equation (1) can be rewritten as an infinite moving average model, as such:

$$
x_{t}=\sum_{i=0}^{\infty} A_{i} \varepsilon_{t-i}+\varepsilon_{t}
$$

The parameter matrices, $\mathrm{A}_{\mathrm{i}}$, are recursively defined as follows: $A_{1}=\varphi_{1} A_{i-1}+\varphi_{2} A_{i-2}+\ldots$ $+\varphi_{p} A_{i-p}$ and with $A_{0}$ a $k x k$ identity matrix. The variance decompositions allow the 
fraction of the $H$-step ahead error variance in forecasting $x_{i}$ owing to shocks arising from $x_{j}$, where $i \neq j$ to be calculated.

The H-step-ahead forecast error variance decomposition is given by:

$$
\theta_{i j}(H)=\frac{\sigma_{i i}^{-1} \sum_{h=0}^{H-1}\left(e_{j}^{\prime} A_{h} \Sigma e_{i}\right)^{2}}{\sum_{h=0}^{H-1}\left(e_{j}^{\prime} A_{h} \Sigma A_{h}^{\prime} e_{j}\right)}
$$

where $\Sigma$ is the (estimated) variance matrix of the error vector $\varepsilon, \sigma_{i i}$ the (estimated) standard deviation of the error term for variable $i$, and $e_{i}$ is the selection vector with one as the ith element and zero otherwise.

Each element of the variance decomposition matrix is then normalised by the sum of the elements of each row of the decomposition as such:

$$
\tilde{\theta}_{i j}^{g}(H)=\frac{\theta_{i j}^{g}(H)}{\sum_{j=1}^{k} \theta_{i j}^{g}(H)}
$$

This is to ensure that the own and cross-variable variance contribution sum to one under the generalised decomposition with $\sum_{j-1}^{k} \tilde{\theta}_{i j}^{g}(H)=1$ and $\sum_{i, j-1}^{k} \tilde{\theta}_{i j}^{g}(H)=k$ by construction.

The total spillover index is then defined as:

$$
\operatorname{TS}^{g}(H)=\frac{\sum_{i, j=1, i \neq j}^{k} \tilde{\theta}_{i j}^{g}(H)}{\sum_{j=1}^{k} \tilde{\theta}_{i j}^{g}(H)} x 100
$$

The directional spillover to variable $i$ from all other variables $j$ is given by:

$$
D S_{j \rightarrow i}^{g}(H)=\frac{\sum_{j=1, i \neq j}^{k} \tilde{\theta}_{i j}^{g}(H)}{\sum_{j=1}^{k} \tilde{\theta}_{i j}^{g}(H)} x 100
$$

With the reverse, i.e., from market $i$ to all other markets $j$ is given by:

$$
D S_{i \rightarrow j}^{g}(H)=\frac{\sum_{j=1, i \neq j}^{k} \tilde{\theta}_{j i}^{g}(H)}{\sum_{j=1}^{k} \tilde{\theta}_{j i}^{g}(H)} x 100
$$

From these last two measures we can then determine the net spillover from markets $i$ to 
markets $j$ as the difference between equation (7) and equation (6):

$$
N S_{i}(H)=D S_{i \rightarrow j}^{g}(H)-D S_{j \rightarrow i}^{g}
$$

\section{Data and Results.}

\subsection{Data}

We use weekly data on the main Turkish stock index, the BIST, as well as stock index data for the US (S\&P 500) as the largest global market and Germany (DAX) as the largest market closest to Turkey as well as a major trading partner. We also use the exchange rate between the Turkish Lira and the Euro and the US Dollar. The commodity index is represented by the S\&P GSCI. We choose a general commodity index as Turkey has a range of natural resources, this includes oil and gas production, although Turkey is a net importer of both. Moreover, Turkey produces a wide range of minerals, including copper, gold, iron, mercury and uranium as well as coal. Thus, the choice of an individual commodity index may miss important information. ${ }^{3}$ The data is collected over the sample period from the start of 1999 until the $12^{\text {th }}$ of March 2015, giving a total of 846 time series observations. The data is collected Datastream.

One question to be answered when examining spillover behaviour is the frequency of the data to be analysed. One argument is to use the highest possible frequency available. For example, McMillan and Speight (2010) use 5-minute intra-day data. While, intra-day data is not available to us, daily data could be considered. Indeed, Diebold and Yilmaz (2012) use daily data. However, one complicating factor with daily data concerns the issue of time zones and overlapping market openings. The analysis of exchange rate data is unaffected by this issue, as the foreign exchange market is

\footnotetext{
${ }^{3}$ It is also worth noting that oil and gas constitute nearly $80 \%$ of the index and thus, an individual oil index is unlikely to generate different results.
} 
essentially a 24-hour market. Equally, the data used in Diebold and Yilmaz are all US based. However, this becomes an issue when considering markets from different locations around the world. The original Diebold and Yilmaz (2009) uses weekly data for a range of international markets. ${ }^{4}$ Weekly data us also utilised by Beirne et al (2013), Skintzi and Refenes (2006), Louzis (2013) and Yarovaya et al (2016) among others. Therefore, we proceed with weekly data.

Summary statistics for the weekly returns are reported in Table 1. Panel A presents the usual statistics, of note, the BIST has the highest mean return as well as the highest standard deviation, while for all markets the standard deviation is larger than the mean value, a common result with financial data. All series exhibit non-normality with excess kurtosis. The two exchange rate series exhibit positive skewness while all other series had negative skewness. Furthermore, the two exchange rate series exhibit a noticeably larger degree of skewness and excess kurtosis than the other series. Panel B reports the correlation coefficients between our series. Here, we can note two large positive correlations, one between the two exchange rate series and one between the German and US stock market returns. These large values are perhaps not surprising given the interrelated nature of these assets within the global economy. Elsewhere, we can note negative correlations between the exchange rate series and the stock and commodity returns series, while commodity and stock returns are positively correlated.

\subsection{Return and Volatility Spillovers. ${ }^{5}$}

The results for the return spillovers are presented in Table 2. As a general comment, we

\footnotetext{
${ }^{4}$ The markets are seven developed markets (US, UK, France, Germany, Hong Kong, Japan and Australia) and twelve emerging markets (Indonesia, South Korea, Malaysia, Philippines, Singapore, Taiwan, Thailand, Argentina, Brazil, Chile, Mexico and Turkey).

${ }^{5}$ In estimating the VAR's the lag lengths are determined by the Schwarz information criteria and are one lag for returns and two for volatility. We conducted some experimentation by doubling the lag length and using the Akiake information criteria by the nature of tee results is unaffected.
} 
can see that for each series, over $50 \%$ of the variation arises from the series itself and this is typical. Taking each series in turn, regarding the cross-market spillovers, for the BIST30, we can see that the largest spillovers are from the German (7.2\%) and US $(7.8 \%)$ stock market indices, with spillover from the US Dollar of a similar magnitude (6.6\%). The spillovers from the Euro and the commodity market are noticeably smaller (3.9\% and $2.1 \%$, respectively). For the commodity market, the largest spillover is from the US stock market (6.9\%), but the spillovers from all other markets are small. Looking at the international stock markets of Germany and the US, we can see that each market has a large spillover effect on the other of almost equal magnitude, with a spillover from the US to Germany accounting for $32.4 \%$ of the variation of the latter, while the reverse spillover is $31.3 \%$. A similar pattern is found for the two currencies as well, with spillovers from the US Dollar accounting for $36.6 \%$ of the Euro rate movement and the reverse spillover being $33.9 \%$.

Overall, for the return spillovers, the largest spillover effects emanate from the two international stock markets and the two exchange rates, while the smallest spillover arises from the commodity index. Equally, in terms of the series receiving the spillovers again the two international stock market returns and the two currency returns receive the largest and the commodity index the smallest. The result of this is that the net spillover effects are small. This shows the interdependent nature of these markets. The timevarying spillover index is reported in Figure 1. This demonstrates a noticeable step increase in spillovers around the second half of 2008. Prior to this point, spillovers were relatively stable. There is also a noticeable increase in spillovers before slightly falling back during the second half of 2012.

The volatility spillovers show a broadly similar pattern. For the volatility of the BIST returns there are small spillovers arising from the two international stock markets 
but very limited evidence of spillovers elsewhere. For the commodity return series, there is a noticeably larger spillover from the volatility of the US stock returns to commodity volatility (25.7\%), while the volatility of the German stock market is smaller $(8.5 \%)$. For the two international stock markets, again, they exhibit spillovers between themselves, with the spillover from US volatility accounting for $35.5 \%$ of the movement of German stock volatility, while the reverse is $23.6 \%$. Equally, the two exchange rate series exhibit a noticeable spillover between each other, with $44.1 \%$ of the Euro rate volatility arising from a spillover from the US rate volatility and a similar $44 \%$ in reverse.

As with the return series, most of the volatility spillovers emanate from and are received by the two international stock markets and the two currencies. Although, it is now noticeable that, on the basis of net spillovers, information from US stock returns spillovers to other markets the most. However, it is noticeable that volatility spillovers from the Turkish stock market to the volatility of both currencies occur with reasonable magnitude. Again, the graph of the time-varying spillover index, reported in Figure 2, shows a step change in behaviour towards the end of 2008, which is partially reversed in the second half of 2012. This clearly highlights the effect of the financial crisis.

These results show return and volatility spillovers of approximately similar size occurring between the German and US stock market series and equally between the two currencies. Comparatively, there are less spillovers to and from the Turkish stock market and the commodity market, suggesting a degree of separation for these markets.

\section{Sub-Sample Evidence: Spillovers Across Two Crises}

To provide further analysis and understanding of the results, we split the sample in two (almost) equal halves and re-estimate the spillovers model for returns and volatility. We can see from the two time-varying spillovers graphs that spillovers increase in the 
second half of the sample but this analysis will provide greater detail. Therefore, we reestimate the models from the beginning of the sample in 1999 to the end of 2006 and then from the beginning of 2007 to the end of the sample in 2015. As noted, this divides our full sample into two halves of 418 and 428 observations respectively. Moreover, it also separates the sample between the dotcom crash and the crash associated with the financial crisis. The return spillovers are presented in Table 4 and the volatility spillovers in Table 5.

Examining return spillovers, in the first sub-sample we can make the following observations. Most obviously, the level of spillovers is relatively low and net spillovers for all markets are close to zero. Where notable spillovers do occur, they fall within the same asset class. Thus, we see spillovers between the Euro and Dollar exchange rates and between the DAX and S\&P stock indexes. In contrast, the Turkish stock market and the commodity market both appear largely independent of the other markets, with very limited evidence of spillovers. In the second sub-sample, we see a different picture with spillovers much increased. Here, we can see evidence that the BIST and commodity markets are much more integrated with the other markets under consideration. Notably, spillovers from the DAX and S\&P affect the commodity market, while the same two markets plus the US Dollar affect the BIST. Overall, it is evident that this period, which includes the financial crisis, is marked by greater interrelations and dependence between markets than in the period marked by the dotcom crash.

The volatility spillovers are presented in Table 5 and provide a very similar picture to the return spillovers across the two sub-sample periods. The spillover index is relatively low in the first sub-sample and then doubles in the second sub-sample. In the first period, spillovers are largely confined to markets trading the same asset type, notably between the two exchange rate series and the DAX and S\&P stock indexes. The 
commodity market appears largely independent from the other markets considered and that is broadly true of the BIST, although there is some evidence that spillovers from it affect the two exchange rate markets. In the second sub-sample there is greater evidence of spillovers arising from all markets and having effects across all markets. Suggesting that the degree of market integration and dependency has increased since 2007. Indeed, as an example of the increased interrelations between the volatility series during the second half of our sample, for all series over $50 \%$ of the movement arises from other markets. In the first half of the sample that only arose for the two exchange rate series.

To further enhance the analysis of spillovers between our markets and how they change over time, we present, in Figures 3-8, the spillover plots that indicate the spillovers that emanate from each market, that spillovers to each market as well as net spillovers between assets. Examining the return spillovers first, the graphs in Figures 35 present a similar picture to that reported in the tables. Over the first half of the sample spillovers to and from the different markets largely operate through the two exchange rate series and the two developed stock market series. Notwithstanding that, however, net spillovers are low. This confirms the view of greater market segmentation between the developed and emerging markets and the commodity and other markets in the first half of the sample. Over the second half of the sample, we can see that the nature of this result changes. The spillovers from and to the commodity market noticeably jump to a higher level towards the end of 2008 and the beginning of 2009. The spillover to and from the Turkish stock market also increase but at a more steady pace over the period from 2005 to 2008 . The net spillovers also increase noticeably in the second half of the sample. With the US stock market and the Dollar exchange rate having a particularly large effect on the Turkish stock market and commodities in general. The German stock market also has a noticeable impact on the Turkish stock market and the behaviour of 
the commodities market, although the euro exchange rate effect is more muted.

Examining the volatility spillovers from and to each market and the net spillovers, reported in Figures 6-8, the results again support the view that the nature of spillovers changes over the full sample period. Over the first half of the sample, spillovers are dominated by the two exchange rate series. There is also a noticeable increase in spillovers related to the Turkish stock market towards the end of 2004. Volatility spillovers from the German and US stock markets also increase from the start of the sample until around 2006 before declining again. Commodity spillovers, however, are low throughout the first half of the sample. During the second half of the sample, spillovers across all markets and assets appear higher. Although, it is noticeable that spillovers drop to almost zero in the second half of 2008. This occurs just prior to the sizeable price falls in most markets with the full extent of the financial crisis becoming clear and is marked by a period of low volatility across all markets. It can also be observed that there is a downward step change in the spillovers across most markets towards the of 2012. Over this period, while the global financial crisis has abated, individual debt crises afflicted Europe (sovereign debt of Southern European markets) and the US (congress debt ceiling debates). Thus, market interaction may decline as the crises are location specific. This is more apparent in the spillovers arising from markets rather than to markets. The net spillovers also appear to show that while spillovers are generally low in the first half of the sample, there is a much greater flow of information between markets from late 2008 onwards. Indeed, there is a noticeable effect between the Turkish stock market and commodities, while the two exchange rates and the US stock market also exhibit noticeable net spillover effects.

Having obtained a range of results regarding the mean and return spillover effects we can make several observations. Across both the return and volatility 
spillovers between the three stock markets, two foreign exchange markets and the commodity market there is a clear step change in spillovers, which increase substantially around 2007/2008. Moreover, it can be observed that spillovers arriving to and emanating from the Turkish stock market and the commodity market noticeably increase in the second half of our sample. Regarding the volatility spillovers we can compare our results with those of Diebold and Yilamz (2012) who examine such spillovers between US stocks, interest rates, exchange rates and a global commodity index. Most noticeable, is that Diebold and Yilmaz report a (very) low volatility spillover from US stocks to commodities (0.46), whereas we report a much higher level of spillover (25.7). This difference in fact highlights one of our main results. The volatility spillover reported in the first half of our sample (1.5) is closer to the Diebold and Yilmaz result. Moreover, an examination of the net spillovers in Figure 8 reveals that US stock-commodity spillovers noticeably increased towards the end of 2010 and even more so in 2011 and 2012. The Diebold and Yilmaz sample that ends in January 2010 thus misses this increase in spillovers. Hence, this paper reports an important change in market dynamics between US stocks and commodities.

As discussed above, much of the current work examining spillovers focuses on similar assets across markets or different assets in the same market. Thus, the results here serve in helping to establish a more complete set of results and an understanding of the interrelations between assets and markets. In related work, and in additional to the work cited in Sections 1 and 2, Mensi et al (2013) report spillover effects between US stocks and both oil and gold. Consistent with our results here, the literature reports a change in market behaviour since the onset of the financial crisis. Creti et al (2013) report an increase in correlations between stocks and commodities. Chen and Wu (2016), using the Diebold and Yilmaz framework, report an increase in spillovers 
between different commodities following the crises, although subsequently spillovers have again declined. Further work has examined the spillover behaviour between international stock markets, between stocks and bonds and between stocks and exchange rates (see, for example, Dean et al, 2010; Kumar, 2013; Kim and Ryu, 2015; Varovaya et al, 2016). This paper, which covers developed and emerging stock markets, exchange rates and commodities, thus contributes by extending the evidence base that reveals the time-varying nature of spillovers and notably how they have changed substantially in the past ten years.

\section{Summary and Conclusion.}

This paper seeks to examine stock return mean and volatility spillovers for Turkey, a large emerging market, with the commodity market, two key exchange rates (US Dollar and the Euro) and two large international stock markets (DAX and S\&P500). The aim

of the paper is, first, to extend the existing evidence that mainly focusses on industrial markets by examining Turkey and, second, to consider how spillovers have varied over the recent past, which includes both the dotcom and financial crisis periods.

Using the Diebold-Yilmaz spillover index methodology, we examine spillovers both over the full sample that covers from 1999 to early 2015 as well as two subsamples that are split at the end of 2006. Thus, the sub-sample analysis separates the dotcom and financial crisis periods. Indeed, these sub-samples highlight important differences in spillovers between these two periods. Over the first sub-sample there are only noticeable spillovers within markets trading the same asset class. Thus, there are spillovers between the German and US stock markets and exchange rates. The Turkish stock market and the commodity market appears relatively separate, with little spillovers to or from these markets. However, after 2006 the extent of spillovers 
increase. Both the mean and volatility spillovers index approximately double, while for the volatility series, $50 \%$ of the movement arises from other market spillovers, for the mean returns at least $40 \%$ of the movements arises from spillovers. Thus, there is a greater degree of interrelation and interdependence post the financial crisis. This change in spillover behaviour can also be seen in the spillover graphs, which highlight a step increase in 2008, again with noticeable increases for Turkish stocks and commodity's. Indeed, examining pairwise spillovers highlights this changing nature of the spillovers and shows how market interrelations have changed since around 2008.

Therefore, the key message arising from this paper is that spillovers have risen largely as a result of the financial crisis and that spillovers occur across all markets. But that this behaviour does not occur with all periods of market stress, following the dotcom fall, spillovers were confined to the same asset type. Thus, these results stress the view that greater interrelations between asset types now occur. Across mean and volatility spillovers, the US Dollar and US stock market appear the main giver of spillovers with the Euro and the commodity market the main receivers. We believe that these results will be of interest to academics in generating models to explain market behaviour. Also to practitioners who can incorporate the information provided here in building portfolios and understanding how movements in one asset affects those in another. We also believe these results will be of use to policy authorities in understanding how domestic asset values can be affected by movements in international markets, which in turn can affect investment and consumption decisions within the domestic economy. 


\section{References.}

Ajayi, R. A. and M. Mougoue (1996), "On the dynamic relation between stock prices and exchange rates", Journal of Financial Research 19, 193-207.

Aloui, C., D. K. Nguyen and H. Njeh (2012), "Assessing the impacts of oil price fluctuations on stock returns in emerging markets", Economic Modelling, 29, 26862695.

Antonakakis, N. (2012), "Exchange return co-movements and volatility spillovers before and after the introduction of euro", Journal of International Financial Markets, Institutions and Money 22, 1091-1109.

Apergis, N. and A. Rezitis (2001), "Asymmetric cross-market volatility spillovers: Evidence from daily data on equity and foreign exchange markets", The Manchester School 69, 81-96.

Arouri, M., J. Jouini and D. K. Nguyen (2011), "Volatility spillovers between oil prices and stock sector returns: Implications for portfolio management", Journal of International Money and Finance, 30, 1387-1405.

Arouri, M., J. Jouini and D. K. Nguyen (2012), "On the impacts of oil price fluctuations on European equity markets: Volatility spillover and hedging effectiveness", Energy Economics, 34, 611-617.

Artis, M. J. and M. P. Taylor (1988), "Exchange rates, interest rates, capital controls and the European Monetary System: Assessing the track record", in F. Giavazzi, S. Micossi and M. Miller: The European Monetary System, Cambridge University Press, Cambridge, 185-206.

Baillie, R. T. and T. Bollerslev (1991): "Intra-day and inter-market volatility in foreign exchange rates", Review of Economic Studies 58, 565-585.

Beirne, J. , G. M. Caporale, M. Schulze-Ghattas and N. Spagnolo (2013), "Volatility spillovers and contagion from mature to emerging stock markets", Review of International Economics 21, 1060-1075.

Black, A. J., Klinkowska, O., McMillan, D. G., and McMillan, F. J. (2014), "Forecasting stock returns: Do commodity prices help?" Journal of Forecasting 33, 627-639.

Bonfiglioli, A. and C. A. Favero (2005), "Explaining co-movements between stock markets: The case of US and Germany", Journal of International Money and Finance 24, 1299-1316.

Bubák, V., E. Kocenda and F. Zikes (2011), "Volatility transmission in emerging European foreign exchange markets", Journal of Banking \& Finance 35, 2829-2841.

Büyükşahin, B., M. S. Haigh and M. A. Robe (2010), "Commodities and equities: Ever a 'market of one'?", Journal of Alternative Investments, 12, 76-95. 
Büyükşahin, B. and M. A. Robe (2014), "Speculators, commodities and cross-market linkages", Journal of International Money and Finance, 42, 38-70.

Caporale, G. M., N. Pittis and N. Spagnolo (2006), "Volatility transmission and financial crises", Journal of Economics and Finance 30, 376-390.

Che, S. and X. Wu (2016), "Comovements and Volatility Spillovers in Commodity Markets”, Texas A\&M University, Department of Agricultural Economics, WP.

Chinzara, Z. and M. J. Aziakpono (2009), "Dynamic returns linkages and volatility transmission between South African and world major stock markets", Studies in Economics and Econometrics 33, 69-94.

Choi, K. and S. Hammoudeh (2010), "Volatility behavior of oil, industrial commodity and stock markets in a regime-switching environment", Energy Policy, 38, 4388-4399.

Creti, A., M. Joëts and V. Mignon (2013), "On the links between stock and commodity markets' volatility”, Energy Economics, 37, 16-28.

Dean, W.G., R.W. Faff and G.F. Loudon (2010), "Asymmetry in return and volatility spillover between equity and bond markets in Australia", Pacific-Basin Finance Journal $18,272-289$.

Delatte, A.-L. and C. Lopez (2013), "Commodity and equity markets: Some stylized facts from a copula approach", Journal of Banking \& Finance, 37, 5346-5356.

Diebold, F. and K. Yilmaz (2009). Measuring financial asset return and volatility spillovers, with application to global equity markets. Economic Journal, 119, 1-14.

Diebold, F. and K. Yilmaz, K. (2012), 'Better to give than to receive: Predictive directional measurement of volatility spillovers', International Journal of Forecasting, 28, 57-66.

Engle, R. F., T. Ito, and W.-L. Lin (1990), "Meteor showers or heat waves? Heteroskedastic intra-daily volatility in the foreign exchange market", Econometrica 58, 524-542.

Fu, T. Y., M. J. Holmes and D. F. S. Choi (2011), "Volatility transmission and asymmetric linkages between the stock and foreign exchange markets: A sectoral analysis", Studies in Economics and Finance 28, 36-50.

Hong, Y. (2001): "A test for volatility spillover with application to exchange rates", Journal of Econometrics 103, 183-224.

Huang, R. D., R. W. Masulis and H. R. Stoll (1996), "Energy shocks and financial markets", Journal of Futures Markets, 16, 1-27. 
Huang, B.-N. and C. W. Yang (2002), "Volatility of changes in G-5 exchange rates and its market transmission mechanism", International Journal of Finance \& Economics 7, 37-50.

Inagaki, K. (2007), "Testing for volatility spillover between the British pound and the euro", Research in International Business and Finance 21, 161-174.

Jones, C. M. and G. Kaul (1996), "Oil and the stock markets", Journal of Finance, 51, 463-491.

Jouini, J. (2013), "Return and volatility interaction between oil prices and stock markets in Saudi Arabia", Journal of Policy Modeling, 35, 1124-1144.

Kanas, A. (2000) "Volatility spillovers between stock returns and exchange rate changes: International evidence", Journal of Business Finance \& Accounting 27, 447467.

Kanas, A. (2002), "Is exchange rate volatility influenced by stock return volatility? Evidence from the US, the UK and Japan”, Applied Economics Letters 9, 501-503.

Kang, W., R. A. Ratti and K. H. Yoon (2015), "The impact of oil price shocks on the stock market return and volatility relationship", Journal of International Financial Markets, Institutions and Money, 34, 41-54.

Kearney, C. and A. J. Patton (2000), "Multivariate GARCH modeling of exchange rate volatility transmission in the European Monetary System", The Financial Review 35, $29-48$.

Kim, J.-S. and D. Ryu, (2015), "Return and Volatility Spillovers and Cojump Behavior Between the U.S. and Korean Stock Markets", Emerging Markets Finance and Trade 51, S3-S17.

Kitamura, Y. (2010), "Testing for intraday interdependence and volatility spillover among the euro, the pound and the Swiss franc markets", Research in International Business and Finance 24, 158-171.

Koop, G., M. H. Pesaran and S. Potter (1996), "Impulse Response Analysis in Nonlinear Multivariate Models", Journal of Econometrics, 74, 119-148.

Kumar, M. (2013), "Returns and volatility spillover between stock prices and exchange rates: Empirical evidence from IBSA countries", International Journal of Emerging Markets 8, 108-128.

Kyle, A. S. (1985), "Continuous auctions and insider trading”, Econometrica 53, 13151335 .

Laopodis, N. T. (1998), “Asymmetric volatility spillovers in deutsche mark exchange rates", Journal of Multinational Financial Management 8, 413-430. 
Louzis, D. (2013), "Measuring return and volatility spillovers in euro area financial markets", Bank of Greece, Working Paper 154.

Malik, A. K. (2005), "European exchange rate volatility dynamics: An empirical investigation", Journal of Empirical Finance 12, 187-215.

McMillan, D. G. and A. E. H. Speight (2010), "Return and volatility spillovers in three euro exchange rates", Journal of Economics and Business 62, 79-93.

Mensi, W., M. Beljid, A. Boubaker and S. Managi (2013), "Correlations and volatility spillovers across commodity and stock markets: Linking energies, food, and gold", Economic Modelling, 32, 15-22.

Miller, J. I. and R. A. Ratti (2009), "Crude oil and stock markets: Stability, instability, and bubbles", Energy Economics, 31, 559-568.

Nikkinen, J., P. Sahlström and S. Vähämaa (2006), "Implied volatility linkages among major European currencies", Journal of International Financial Markets, Institutions and Money 16, 87-103.

Olson, E., A. J. Vivian and M. E. Wohar, (2014), "The relationship between energy and equity markets: Evidence from volatility impulse response functions", Energy Economics, 43, 297-305.

Park, J. and R. A. Ratti (2008), "Oil price shocks and stock markets in the U.S. and 13 European countries”, Energy Economics, 30, 2587-2608.

Pesaran, M. H. and Y. Shin (1998), "Generalized Impulse Response Analysis in Linear Multivariate Models", Economics Letters, 58, 17-29.

Rose, A. K. and L. E. O. Svensson (1994), "European exchange rate credibility before the fall", European Economic Review 38, 1185-1216.

Ross, S. A. (1989), "Information and volatility: The no-arbitrage martingale approach to timing and resolution irrelevancy", Journal of Finance 44, 1-17.

Sadorsky, P. (1999), “Oil price shocks and stock market activity”, Energy Economics, 21, 449-469.

Silvennoinen, A. and S. Thorp (2013), "Financialization, crisis and commodity correlation dynamics", Journal of International Financial Markets, Institutions and Money, 24, 42-65.

Sims, C. A. (1980), "Macroeconomics and Reality", Econometrica, 48, 1-48.

Skintzi, V. D. and Refenes, A. N., (2006). "Volatility spillovers and dynamic correlation in European bond markets", Journal of International Financial Markets, Institutions and Money 16, 23-40. 
Smith, C. E. (1992), "Stock markets and the exchange rate: A multi-country approach", Journal of Macroeconomics 14, 607-629.

Sosvilla-Rivero, S., F. Fernández-Rodríguez and O. Bajo-Rubio (1999), "Exchange rate volatility in the EMS before and after the fall", Applied Economics Letters 6, 717-722.

Vivian, A. and Wohar, M.E., (2012), "Commodity volatility breaks", Journal of International Financial Markets, Institutions and Money 22, 395-422.

$\mathrm{Wu}, \mathrm{R} .-\mathrm{S}$. (2005), "International transmission effect of volatility between the financial markets during the Asian financial crisis", Transition Studies Review 12, 19-35.

Yarovaya, L., J. Brzeszczyński, C.K.M. Lau (2016), "Intra- and inter-regional return and volatility spillovers across emerging and developed markets: Evidence from stock indices and stock index futures", International Review of Financial Analysis 43, 96114.

Yau, H.-Y. and C.-C. Nieh (2006), "Interrelationships among stock prices of Taiwan and Japan and NTD/Yen exchange rate", Journal of Asian Economics 17, 535-552. 
Table 1. Summary Statistics for Returns.

Panel A

\begin{tabular}{|l|l|l|l|l|}
\hline & Mean $(\%)$ & Std. Dev. $(\%)$ & Skewness & Kurtosis \\
\hline BIST & 0.407 & 5.598 & -0.164 & 7.037 \\
\hline COM & 0.047 & 3.330 & -0.465 & 4.656 \\
\hline DAX & 0.103 & 3.325 & -0.589 & 6.291 \\
\hline EUR & 0.239 & 2.374 & 5.062 & 66.267 \\
\hline USD & 0.250 & 2.332 & 5.013 & 63.877 \\
\hline SP & 0.062 & 2.494 & -0.522 & 7.157 \\
\hline
\end{tabular}

Panel B

\begin{tabular}{|l|c|c|c|c|c|c|}
\hline & \multicolumn{6}{|c|}{ Correlations } \\
\hline & BIST & COM & DAX & EUR & USD & SP \\
\hline BIST & 1 & 0.146 & 0.298 & -0.208 & -0.288 & 0.324 \\
\hline COM & & 1 & 0.229 & -0.027 & -0.175 & 0.286 \\
\hline DAX & & & 1 & -0.221 & -0.249 & 0.777 \\
\hline EUR & & & & 1 & 0.821 & -0.223 \\
\hline USD & & & & & 1 & -0.305 \\
\hline SP & & & & & & 1 \\
\hline NOS: & & & & & 1 \\
\hline
\end{tabular}

Notes: BIST is the Turkish stock markets index; COM is the commodity market index; DAX is the German stock market index; Eur is the Euro to the Turkish Lira exchange rate; USD is the US Dollar to the Turkish Lira exchange rate; SP is the US stock market index. 
Table 2. Return Spillovers

\begin{tabular}{|c|c|c|c|c|c|c|c|}
\hline & BIST & $\mathrm{COM}$ & DAX & EUR & USD & SP500 & $\begin{array}{l}\text { From } \\
\text { Others }\end{array}$ \\
\hline BIST & 72.4 & 2.1 & 7.2 & 3.9 & 6.6 & 7.8 & 28 \\
\hline $\mathrm{COM}$ & 2.5 & 83.5 & 4.4 & 0.0 & 2.7 & 6.9 & 17 \\
\hline DAX & 5.4 & 3.4 & 53.0 & 2.6 & 3.3 & 32.4 & 47 \\
\hline EUR & 4.2 & 0.0 & 2.5 & 53.9 & 36.3 & 3.0 & 46 \\
\hline USD & 5.1 & 1.5 & 3.23 & 33.9 & 50.8 & 5.5 & 49 \\
\hline SP & 5.5 & 4.5 & 31.3 & 2.6 & 5.1 & 51.0 & 49 \\
\hline $\begin{array}{l}\text { Contribution } \\
\text { to others }\end{array}$ & 23 & 11 & 49 & 43 & 54 & 56 & 235 \\
\hline $\begin{array}{l}\text { Contribution } \\
\text { including } \\
\text { own }\end{array}$ & 95 & 95 & 102 & 97 & 105 & 107 & $39.2 \%$ \\
\hline $\begin{array}{l}\text { Net } \\
\text { Spillovers }\end{array}$ & -5 & -6 & 2 & -3 & 5 & 7 & - \\
\hline \multicolumn{8}{|c|}{$\begin{array}{l}\text { Notes: BIST is the Turkish stock markets index; COM is the commodity market index; DAX is } \\
\text { the German stock market index; Eur is the Euro to the Turkish Lira exchange rate; USD is the } \\
\text { US Dollar to the Turkish Lira exchange rate; SP is the US stock market index. The first row } \\
\text { refers to the series the spillovers emanate from. The first column refers to the series that receive } \\
\text { the spillovers. The column 'From Others' is the sum of spillover received by the market listed in } \\
\text { the first column. The row 'Contribution to Others' is the sum of spillovers from the market } \\
\text { listed in the first row. The row 'Contribution including own' is the sum of the row 'Contribution } \\
\text { to Others' plus the 'self-spillover'. The row 'Net Spillovers' is the difference between 'From } \\
\text { Others' and 'Contribution to Others'. }\end{array}$} \\
\hline
\end{tabular}


Table 3. Volatility Spillovers

\begin{tabular}{|c|c|c|c|c|c|c|c|}
\hline & BIST & $\mathrm{COM}$ & DAX & EUR & USD & SP500 & $\begin{array}{l}\text { From } \\
\text { Others }\end{array}$ \\
\hline BIST & 90.4 & 0.8 & 3.9 & 0.5 & 0.5 & 3.8 & 10 \\
\hline $\mathrm{COM}$ & 1.8 & 63.6 & 8.5 & 0.2 & 0.2 & 25.7 & 36 \\
\hline DAX & 2.0 & 3.7 & 58.8 & 0.0 & 0.0 & 35.5 & 41 \\
\hline EUR & 11.4 & 0.1 & 0.1 & 44.2 & 44.1 & 0.1 & 56 \\
\hline USD & 11.5 & 0.1 & 0.1 & 44.0 & 44.1 & 0.2 & 56 \\
\hline SP500 & 3.1 & 12.0 & 23.6 & 0.2 & 0.3 & 60.8 & 39 \\
\hline $\begin{array}{l}\text { Contribution } \\
\text { to others }\end{array}$ & 30 & 17 & 36 & 45 & 45 & 65 & 238 \\
\hline $\begin{array}{l}\text { Contribution } \\
\text { including } \\
\text { own }\end{array}$ & 120 & 80 & 95 & 89 & 89 & 126 & $39.7 \%$ \\
\hline $\begin{array}{l}\text { Net } \\
\text { Spillovers }\end{array}$ & 20 & -19 & -5 & -11 & -11 & 26 & - \\
\hline \multicolumn{8}{|c|}{$\begin{array}{l}\text { Notes: BIST is the Turkish stock markets index; COM is the commodity market index; DAX is } \\
\text { the German stock market index; Eur is the Euro to the Turkish Lira exchange rate; USD is the } \\
\text { US Dollar to the Turkish Lira exchange rate; SP is the US stock market index. The first row } \\
\text { refers to the series the spillovers emanate from. The first column refers to the series that receive } \\
\text { the spillovers. The column 'From Others' is the sum of spillover received by the market listed in } \\
\text { the first column. The row 'Contribution to Others' is the sum of spillovers from the market } \\
\text { listed in the first row. The row 'Contribution including own' is the sum of the row 'Contribution } \\
\text { to Others' plus the 'self-spillover'. The row 'Net Spillovers' is the difference between 'From } \\
\text { Others' and 'Contribution to Others'. }\end{array}$} \\
\hline
\end{tabular}


Table 4. Sub-Sample Return Spillovers

\begin{tabular}{|c|c|c|c|c|c|c|c|}
\hline \multicolumn{8}{|c|}{ Sub-Sample 1999-2006 } \\
\hline & Bist & Com & DAX & EUR & USD & SP & $\begin{array}{l}\text { From } \\
\text { Others }\end{array}$ \\
\hline BIST & 84.0 & 0.8 & 4.5 & 3.7 & 3.1 & 4.0 & 16 \\
\hline $\mathrm{COM}$ & 1.9 & 97.0 & 0.5 & 0.2 & 0.1 & 0.3 & 3 \\
\hline DAX & 3.1 & 0.8 & 58.8 & 2.8 & 1.2 & 33.2 & 41 \\
\hline EUR & 5.2 & 0.0 & 2.7 & 50.1 & 38.9 & 3.1 & 50 \\
\hline USD & 4.4 & 0.3 & 1.5 & 39.4 & 51.4 & 3.1 & 49 \\
\hline SP & 2.9 & 1.6 & 32.3 & 3.4 & 2.6 & 57.3 & 43 \\
\hline $\begin{array}{l}\text { Contribution } \\
\text { to others }\end{array}$ & 17 & 3 & 41 & 49 & 46 & 44 & 201 \\
\hline $\begin{array}{l}\text { Contribution } \\
\text { including } \\
\text { own }\end{array}$ & 101 & 100 & 100 & 100 & 0.97 & 101 & $33.6 \%$ \\
\hline $\begin{array}{l}\text { Net } \\
\text { Spillovers }\end{array}$ & 1 & 0 & 0 & -1 & -3 & 1 & - \\
\hline \multicolumn{8}{|c|}{ Sub-Sample 2007-2015 } \\
\hline & BIST & Com & DAX & EUR & USD & SP & $\begin{array}{l}\text { From } \\
\text { Others }\end{array}$ \\
\hline BIST & 45.4 & 4.3 & 11.4 & 8.6 & 18.6 & 11.7 & 55 \\
\hline $\mathrm{COM}$ & 5.2 & 57.8 & 13.7 & 0.2 & 7.5 & 15.7 & 42 \\
\hline DAX & 10.4 & 10.1 & 41.1 & 2.6 & 8.2 & 27.7 & 59 \\
\hline EUR & 10.6 & 0.1 & 3.3 & 56.4 & 25.9 & 3.7 & 44 \\
\hline USD & 16.9 & 4.5 & 8.6 & 19.0 & 40.5 & 10.3 & 59 \\
\hline SP & 10.1 & 10.8 & 27.0 & 2.2 & 10.0 & 39.8 & 60 \\
\hline $\begin{array}{l}\text { Contribution } \\
\text { to others }\end{array}$ & 53 & 30 & 64 & 33 & 70 & 69 & 319 \\
\hline $\begin{array}{l}\text { Contribution } \\
\text { including } \\
\text { own }\end{array}$ & 99 & 88 & 105 & 89 & 111 & 109 & $53.2 \%$ \\
\hline $\begin{array}{l}\text { Net } \\
\text { Spillovers }\end{array}$ & -2 & -12 & 5 & -11 & 11 & 9 & - \\
\hline \multicolumn{8}{|c|}{$\begin{array}{l}\text { Notes: BIST is the Turkish stock markets index; COM is the commodity market index; DAX is } \\
\text { the German stock market index; Eur is the Euro to the Turkish Lira exchange rate; USD is the } \\
\text { US Dollar to the Turkish Lira exchange rate; SP is the US stock market index. The first row } \\
\text { refers to the series the spillovers emanate from. The first column refers to the series that receive } \\
\text { the spillovers. The column 'From Others' is the sum of spillover received by the market listed in } \\
\text { the first column. The row 'Contribution to Others' is the sum of spillovers from the market } \\
\text { listed in the first row. The row 'Contribution including own' is the sum of the row 'Contribution } \\
\text { to Others' plus the 'self-spillover'. The row 'Net Spillovers' is the difference between 'From } \\
\text { Others' and 'Contribution to Others'. }\end{array}$} \\
\hline
\end{tabular}


Table 5. Sub-Sample Volatility Spillovers

\begin{tabular}{|c|c|c|c|c|c|c|c|}
\hline \multicolumn{8}{|c|}{ Sub-Sample 1999-2006 } \\
\hline & BIST & Com & DAX & EUR & USD & SP & $\begin{array}{l}\text { From } \\
\text { Others }\end{array}$ \\
\hline BIST & 94.2 & 0.6 & 1.9 & 0.4 & 0.5 & 2.4 & 6 \\
\hline COM & 0.5 & 93.4 & 3.0 & 0.8 & 0.8 & 1.5 & 7 \\
\hline DAX & 0.7 & 2.4 & 70.9 & 0.2 & 0.2 & 25.7 & 29 \\
\hline EUR & 12.4 & 0.3 & 0.2 & 43.6 & 43.5 & 0.1 & 56 \\
\hline USD & 12.5 & 0.3 & 0.2 & 43.5 & 43.5 & 0.1 & 56 \\
\hline SP & 2.7 & 1.5 & 27.8 & 1.3 & 1.2 & 65.3 & 35 \\
\hline $\begin{array}{l}\text { Contribution } \\
\text { to others }\end{array}$ & 29 & 5 & 33 & 46 & 46 & 30 & 189 \\
\hline $\begin{array}{l}\text { Contribution } \\
\text { including } \\
\text { own }\end{array}$ & 123 & 98 & 104 & 90 & 90 & 95 & $31.5 \%$ \\
\hline $\begin{array}{l}\text { Net } \\
\text { Spillovers }\end{array}$ & 23 & -2 & 4 & -10 & -10 & -5 & - \\
\hline \multicolumn{8}{|c|}{ Sub-Sample 2007-2015 } \\
\hline & BIST & Com & DAX & EUR & USD & SP & $\begin{array}{l}\text { From } \\
\text { Others }\end{array}$ \\
\hline BIST & 50.5 & 7.2 & 9.0 & 5.2 & 13.2 & 14.9 & 50 \\
\hline $\mathrm{COM}$ & 11.8 & 45.6 & 8.3 & 2.2 & 5.8 & 26.2 & 54 \\
\hline DAX & 12.8 & 11.1 & 34.8 & 0.9 & 9.1 & 31.3 & 65 \\
\hline EUR & 9.4 & 7.1 & 9.2 & 34.6 & 22.9 & 16.8 & 65 \\
\hline USD & 12.8 & 8.0 & 13.3 & 12.6 & 31.7 & 21.6 & 68 \\
\hline SP & 16.5 & 15.7 & 16.9 & 1.3 & 8.8 & 40.8 & 59 \\
\hline $\begin{array}{l}\text { Contribution } \\
\text { to others }\end{array}$ & 63 & 49 & 57 & 22 & 60 & 111 & 362 \\
\hline $\begin{array}{l}\text { Contribution } \\
\text { including } \\
\text { own }\end{array}$ & 114 & 95 & 92 & 57 & 92 & 152 & $60.3 \%$ \\
\hline $\begin{array}{l}\text { Net } \\
\text { Spillovers }\end{array}$ & 13 & -5 & -8 & -43 & -8 & 52 & - \\
\hline \multicolumn{8}{|c|}{$\begin{array}{l}\text { Notes: BIST is the Turkish stock markets index; COM is the commodity market index; DAX is } \\
\text { the German stock market index; Eur is the Euro to the Turkish Lira exchange rate; USD is the } \\
\text { US Dollar to the Turkish Lira exchange rate; SP is the US stock market index. The first row } \\
\text { refers to the series the spillovers emanate from. The first column refers to the series that receive } \\
\text { the spillovers. The column 'From Others' is the sum of spillover received by the market listed in } \\
\text { the first column. The row 'Contribution to Others' is the sum of spillovers from the market } \\
\text { listed in the first row. The row 'Contribution including own' is the sum of the row 'Contribution } \\
\text { to Others' plus the 'self-spillover'. The row 'Net Spillovers' is the difference between 'From } \\
\text { Others' and 'Contribution to Others'. }\end{array}$} \\
\hline
\end{tabular}


Figure 1. Time-Varying Return Spillovers.

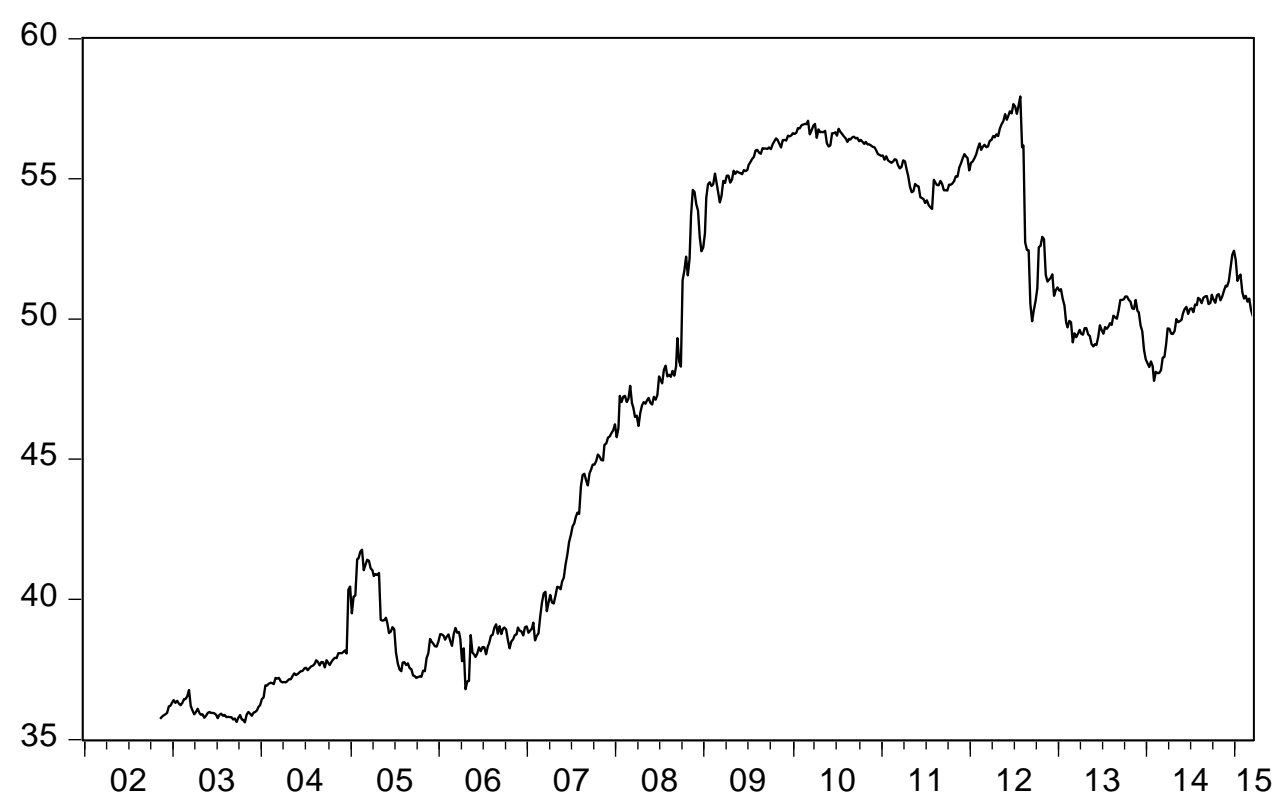

Note: This figure plots the time-varying spillover index between the returns series. 
Figure 2. Time-Varying Volatility Spillovers.

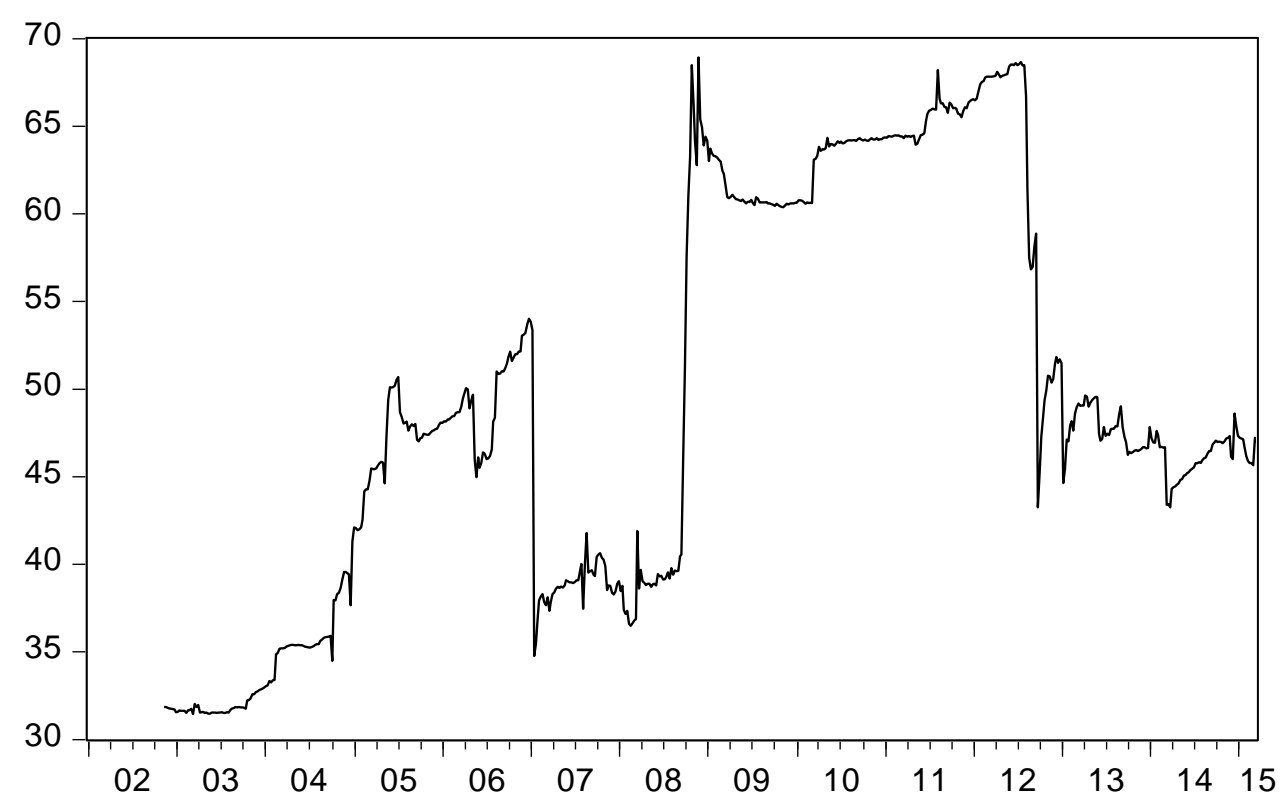

Note: This figure plots the time-varying spillover index between the volatility series. 
Figure 3. Directional Return Spillovers, FROM Each Asset
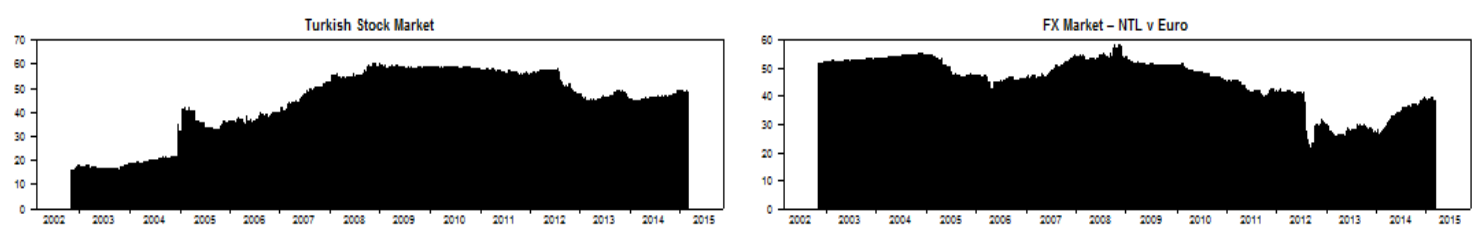

Commodity Market
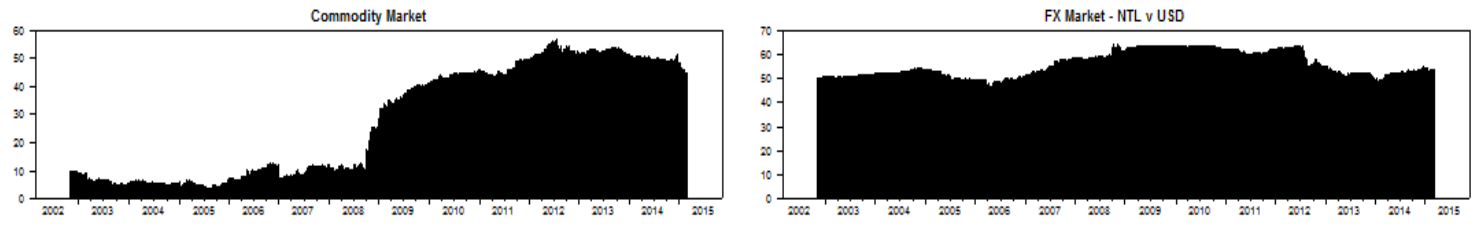

German Stock Market
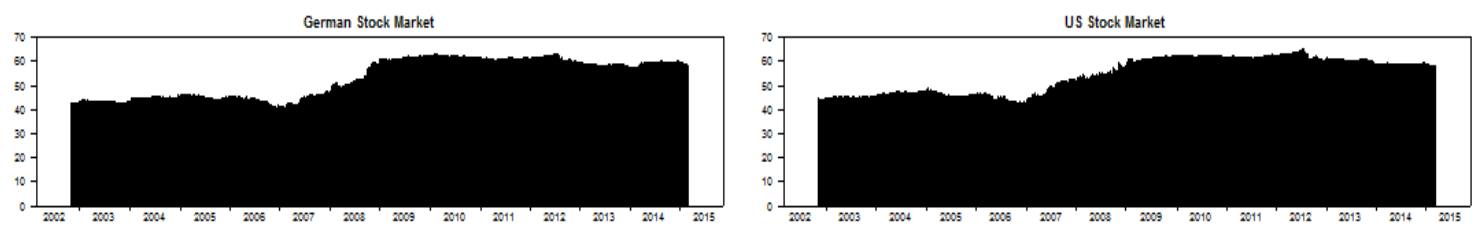

Note: This figure plots the time-varying spillovers arising from each return series. 
Figure 4. Directional Return Spillovers, TO Each Asset
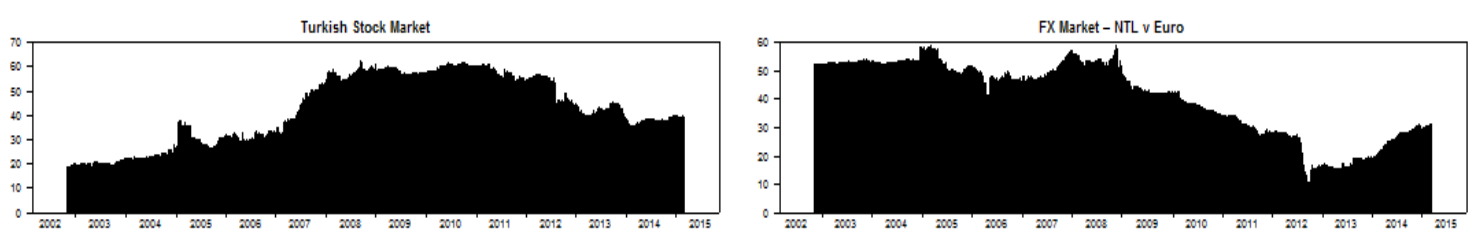

Commodity Market
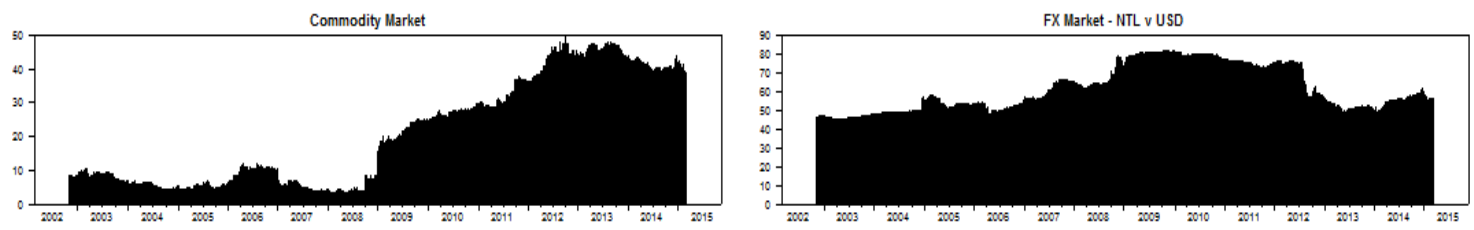

German Stock Market
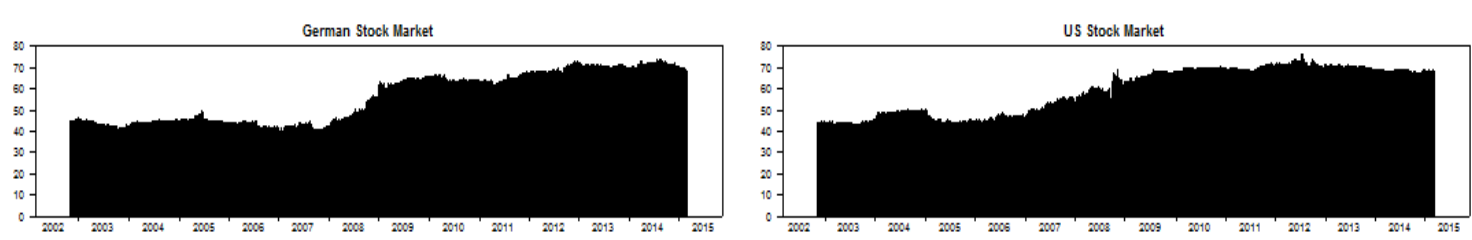

Note: This figure plots the time-varying spillovers flowing to each return series. 
Figure 5. Net Pairwise Return Spillovers

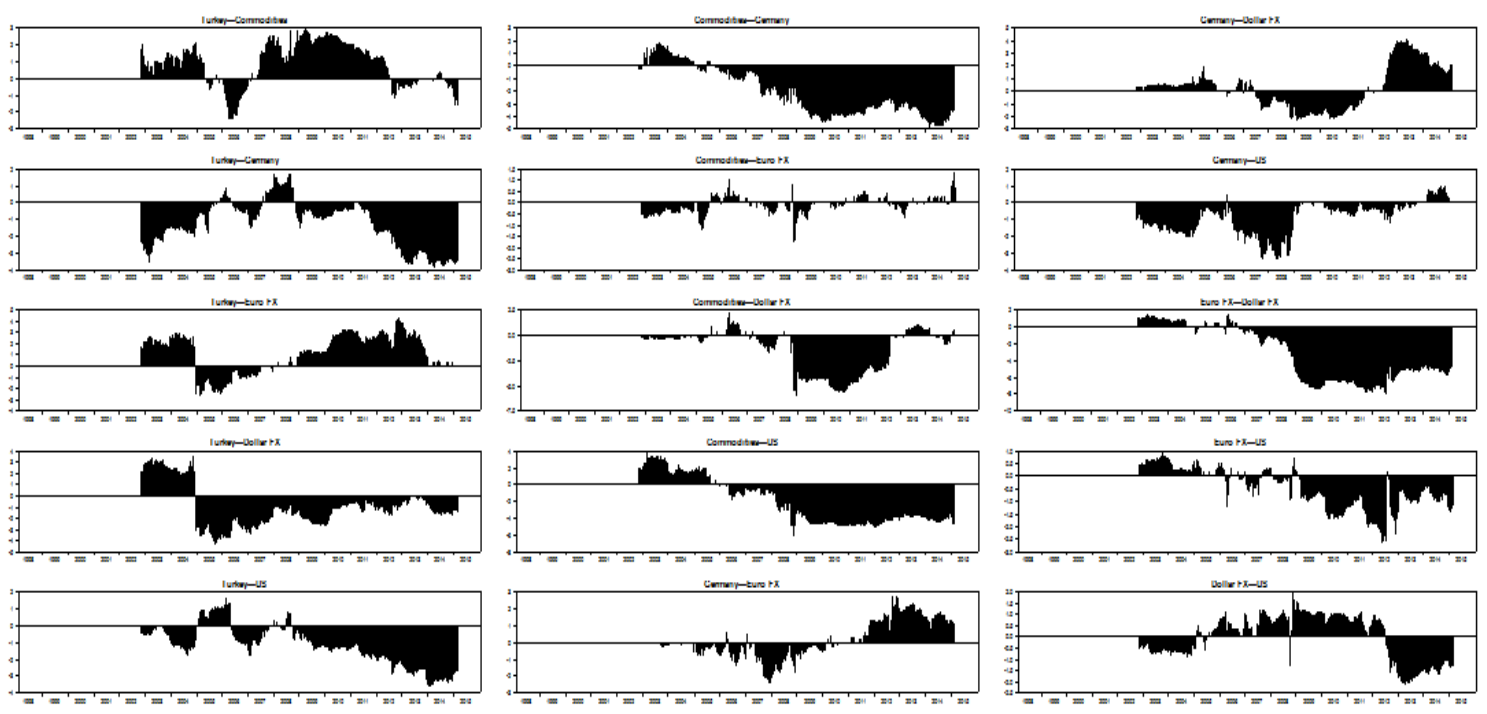

Note: This figure plots the time-varying net spillovers between each return series. 
Figure 6. Directional Volatility Spillovers, FROM Each Asset
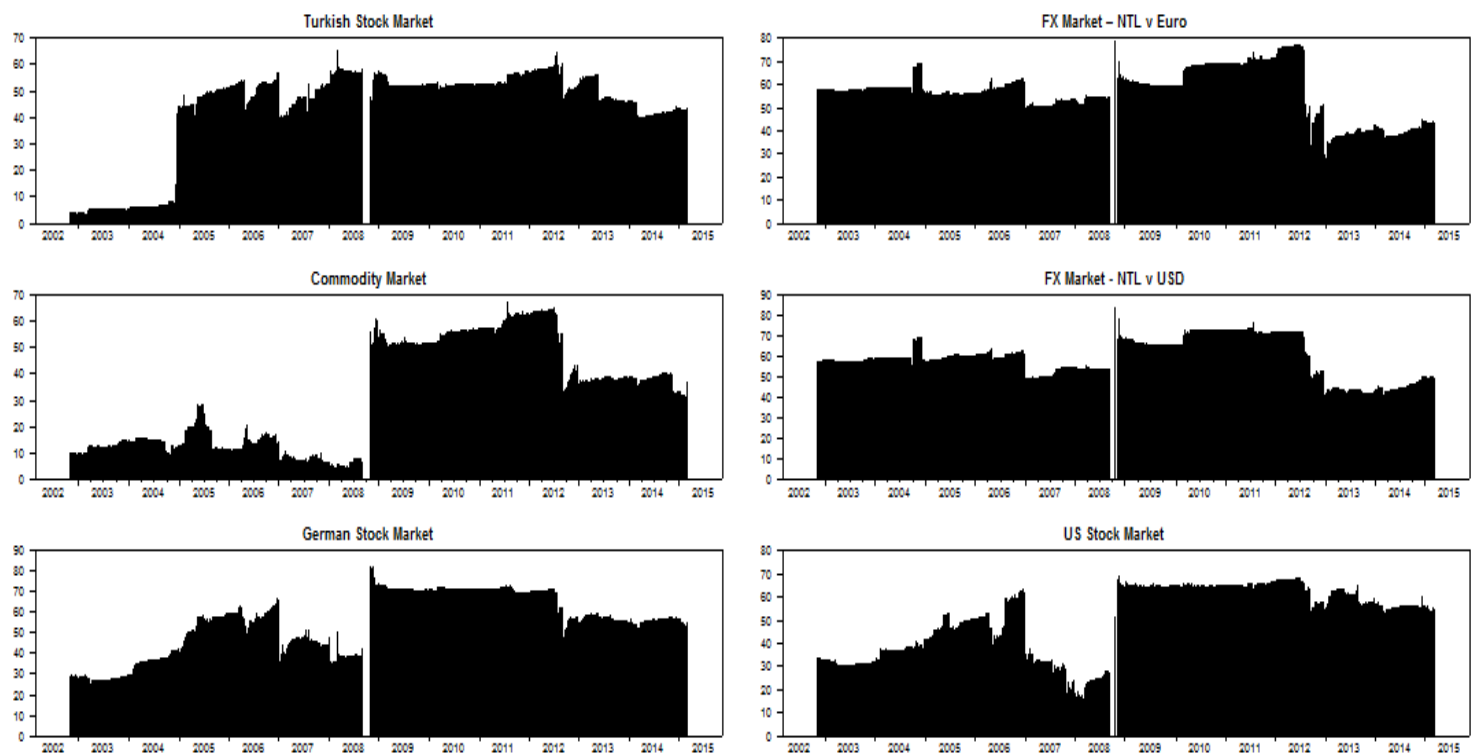

Note: This figure plots the time-varying spillovers arising from each volatility series. 
Figure 7. Directional Volatility Spillovers, TO Each Asset
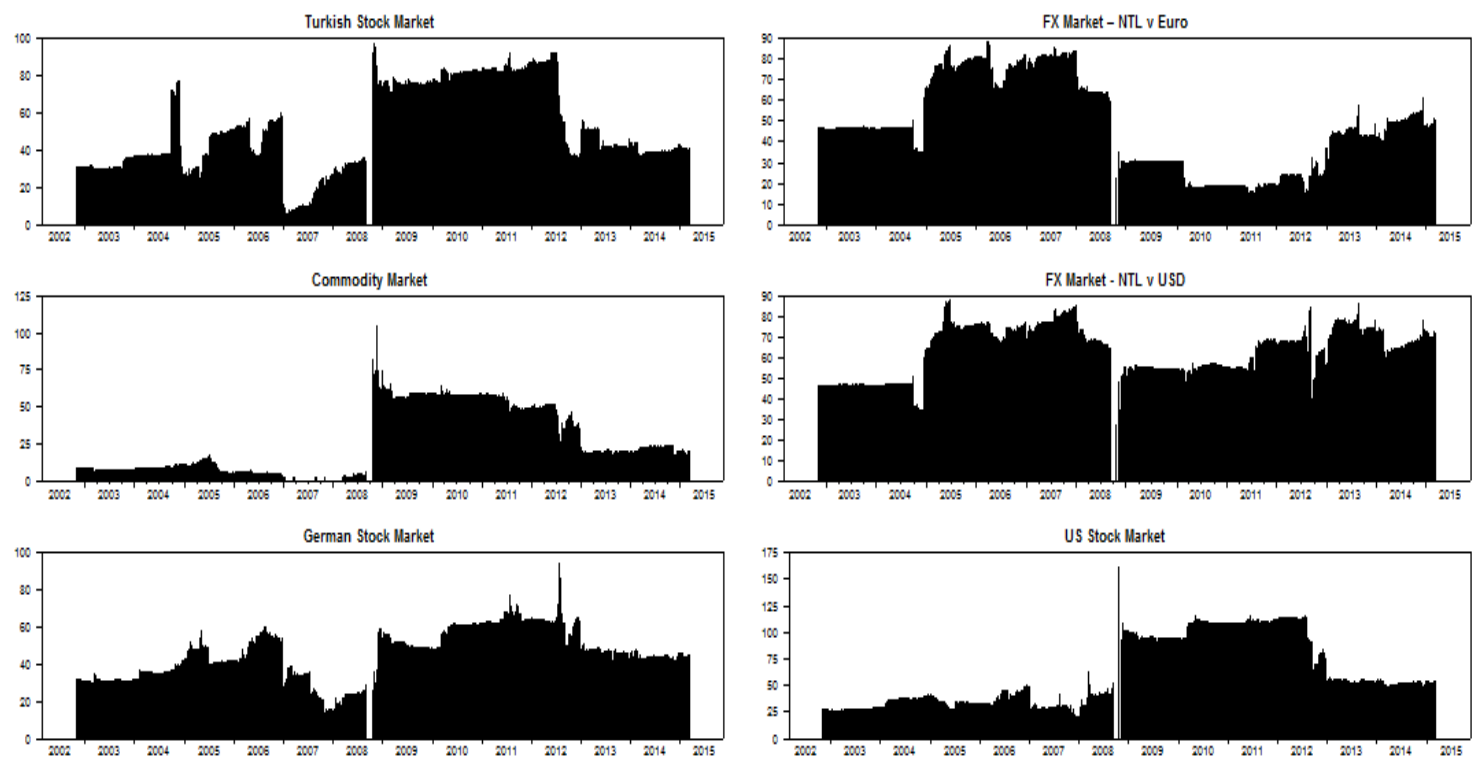

Note: This figure plots the time-varying spillovers flowing to each volatility series. 
Figure 8. Net Pairwise Volatility Spillovers

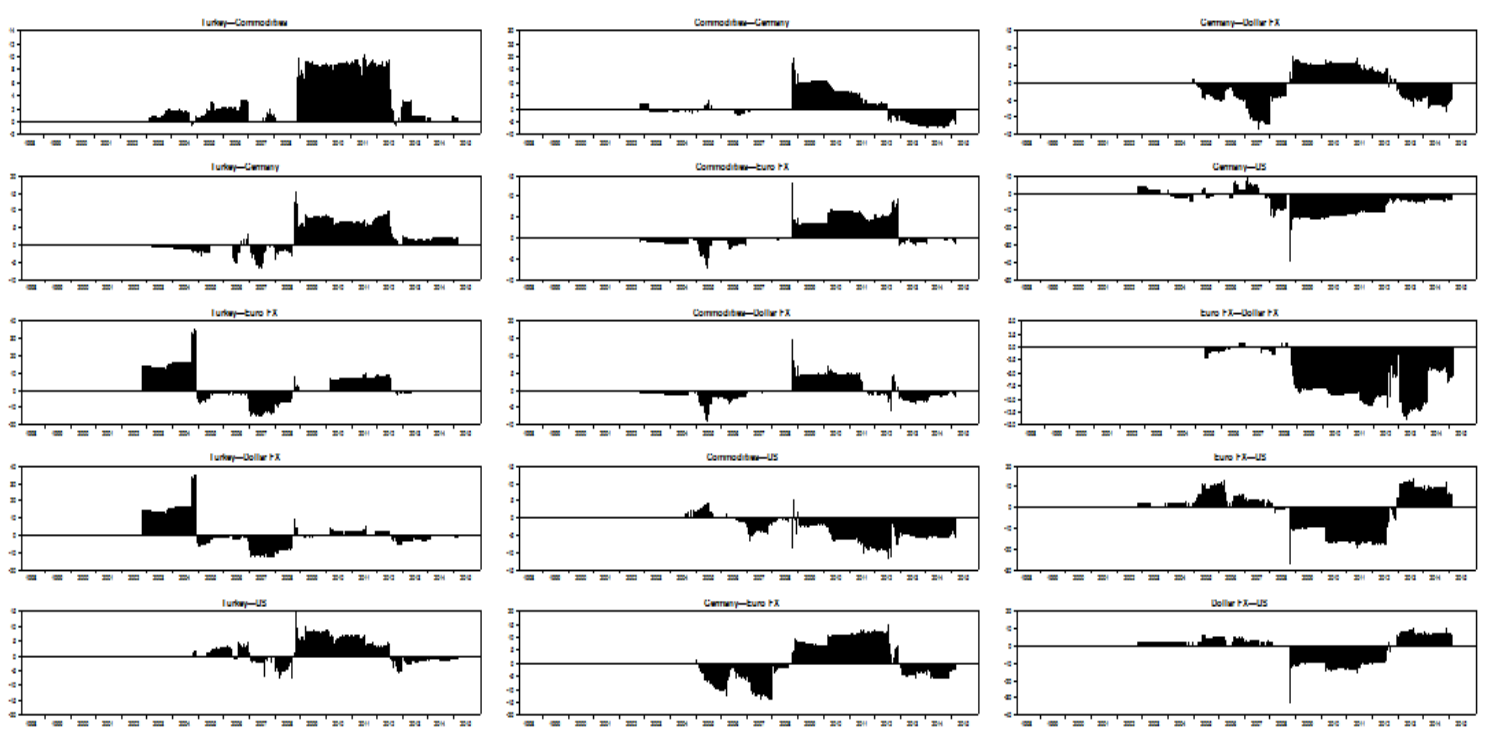

Note: This figure plots the time-varying net spillovers between each volatility series. 